\title{
Graduate Students Perceptions' on Multicultural Education: A Qualitative Case Study ${ }^{1}$
}

\author{
Hasan AYDIN* \\ Betül TONBULOĞLU** \\ Suggested Citation: \\ Aydin, H. \& Tonbuloğlu, B. (2014). Graduate students perceptions' on multicultural \\ education: a qualitative case study. Eurasian Journal of Educational Research, 57, \\ 29-50, http://dx.doi.org/10.14689/ejer.2014.57.3
}

\begin{abstract}
Problem statement: The main responsibility in the implementation of multicultural education, which includes notions like equality, respect, and peace, as well as an equal opportunity for success for all students, belongs to teachers. The teachers' perception of and attitude towards multicultural education are directly related to how they will implement multicultural education. Some past studies indicate that there is an undeniable effect of culture on education, yet teaching candidates and managers often don't have sufficient knowledge of multicultural education. Data gathered from this study is expected to contribute to the literature on multicultural education practices expected to be included in Turkey's educational programs.
\end{abstract}

Purpose of Study: The purpose of this study is to find out the perception of and the evaluation of multicultural education by participants who work as primary and secondary education teachers who are continuing their doctorate level education in curriculum and instruction.

Method: In this inquiry, a qualitative case study approach was used. It has been carried out in the setting of a doctorate level multicultural education class at one of largest state university in Turkey's Educational Science Department. The participants in this study consisted of nine doctorate students taking this course in the Spring of the 2013 academic year, five of which were teachers and four were academicians. Data was collected based on informal interviews, observations, field-notes, and document analysis. A weekly discussion board of reflections, examination papers, and observation forms were also used for more objective results. Gathered data was

1 This study was presented at the 3rd Congress of National Education on Curriculum and Instruction held on 7-9 May 2014 in Gaziantep University

"Correspondin author: Dr. Yildiz Technical University, Faculty of Education, Curriculum and Instruction Dept., e-mail: aydinh@yildiz.edu.tr

* PhD Student, Yildiz Technical University, Faculty of Education, Curriculum and Instruction Dept, Istanbul, e-mail: betultonbuloglu 
evaluated through the "content analysis" technique and the results are presented as a report.

Findings and Results: The findings of this study indicate that equality, democracy, and justice are the most emphasized notions and it has been stated that multicultural education will reinforce these notions. In addition to this, all participants stressed the necessity of taking individual differences into account and expressed that this is cultural richness. Tolerance, respect, and peace are also some of the most commonly mentioned notions.

Conclusions and Recommendations: The need for people with different characteristics and cultures to live with equal rights and every group of the society to have an equal and democratic structure make multicultural education a necessity. Even though the number of studies on multicultural education conducted in Turkey is limited, we recommend that more studies should be conducted like they are in countries with more advanced democracies and that the educational programs should be extended to include multicultural education.

Keywords: multicultural education, equality, democracy, justice, and qualitative research

\section{Introduction}

With the disappearance of boundaries as a result of globalization and the immigration to developed countries in the $21^{\text {st }}$ century, the unitary nature of nationstates has been shaken to its core this leading to the transformation of many of them into multicultural states. This societal transformation has also been observed in the field of education, and the number studies on multicultural education, most widely defined as an idea, an educational reform, and as a process (Banks, 2010), has increased considerably, especially in the last few years (Cirik, 2008).

In addition, the goal of multicultural education is to prepare the students for the world with an ever-increasing diversity(Gaff, 1992; Morey \& Kitano, 1997), and to increase the students' capacity for communicating with others by making them participate actively in the process of learning and by endorsing their experiences in a safe classroom setting (Gay, 2000). Effective teaching in a multicultural classroom necessitates cultural sensitivity strategies and the creation of equal opportunities for academic success and personal development for all students (Sharma, 2011). According to Parekh (2002), multicultural education involves intellectual curiosity, self-criticism, the ability to form an independent opinion by evaluating arguments and proofs, respect toward others, sensitivity for other ways of thinking and living, and activities aimed at moving away from an ethnically oriented mentality. Moreover, it is very important to establish a respect towards different cultures and heightened awareness of individuals by creating a suitable setting for mutual understanding in order to promote multiculturalism (Kaya \& Aydin, 2014).

The main responsibility in the implementation of multicultural education, which includes notions like equality, respect, and peace, as well as an equal opportunity for success for all students, belongs to teachers. The teachers' perception of and attitude 
towards multicultural education are directly related to how they will implement multicultural education, in other words, how they will integrate the differences in the classroom into the educational process around common values (Sharma, 2011). Teachers' roles are also important in order for students to have high expectations in addition to the proper implementation of multicultural education. Studies have shown that teachers' expectations of their students affect the success of the students. Based on this, it is possible to conclude that the teachers' knowledge of and positive attitude towards multicultural education will allow them to reach a target of high success levels for all students.

To become an effective multicultural educator and teacher, a teacher must examine and continuously transform himself/herself. Schlosser (1992) states that the most effective teachers those who can learn the culture of their students and those that students trust. Gorski (2000) insists that teachers have the responsibility to reassess their own prejudices, partiality, and perceptions that can affect the learning experiences of their students.

In this context, the purpose of this study is to examine the perceptions and evaluation of multicultural education of graduate students who work as primary and secondary education teachers as well as people who are continuing their doctorate level education in curriculum and instruction. Some past studies indicate that there is an undeniable effect of culture on education, yet teaching candidates and managers often do not have sufficient knowledge of multicultural education. Data gathered from this study is expected to contribute to the literature on multicultural education practices expected to be included in Turkey's educational programs.

The research question is, "What are the perceptions and evaluation of multicultural education of graduate students who work as primary and secondary education teachers in Turkey?

\section{Notions of Multiculturalism and Multicultural Education}

The notion of multiculturalism includes the awareness of race, ethnic background, language, sexual orientation, gender, age, disability, social class, education, religious orientation and other cultural dimensions (APA, 2002). Aydin (2013) states that, even though there are multiple forms of multiculturalism, it is, in general, an alternative to the "assimilation" mentality in that it recognizes the existence of different cultures in a country, and that this situation signifies a society that creates room for different cultures to grow on their own. To recognize and value the diversity, rather than ignore it, and to not put all the groups in the same level is a better approach than the contrary (Reitz, 2009).

It is possible to find many different definitions of multicultural education by different theorists working in the field (Gay, 1994). With its most widespread definition, multicultural education is considered as an idea, an educational reform, and as a process (Banks, 2010). Basbay and Kagnici (2011) define multicultural education as a process of building the learning and teaching in a way that promotes cultural pluralism, whereas Amney-Dixon (2004) defines it as an educational approach based on democratic values that promotes cultural pluralism. Mitchell 
(1999) gives the definition of multicultural education as educational efforts aimed at creating the necessary positive values for social pluralism by increasing the learning potential of all students, whereas Banks (2010) prefers to define it as education aimed at recognizing and instituting respect and tolerance for differences of age, sexual orientation, disability, social class, ethnicity, color, religion, language and cultural characteristics. Gay (1994) defines multicultural education as an educational policy that has specific values and rules, based on educational rights to ethnic and cultural differences, and that gives equal academic opportunities of success to students. Based on these definitions, it is possible to define multicultural education as a process of creating equal educational opportunities that ensure cultural pluralism within the frame of democratic values by rejecting all kinds of racism and assimilation and respecting all differences. What is meant by multicultural education is not the specialization of formal education for each cultural group, but the sensitivity to multiculturalism in basic education and attention given to diversity by considering multiculturalism in the educational methods (Basbay \&Kagnici, 2011).

Strengths and Weaknesses of Multicultural Education

Ameny-Dixon (2004) and Gay (2003) highlights the strengths of multicultural education as follows:

- Emphasizes notions like democracy, equality and justice.

- Prevents intergroup conflicts by ensuring the coexistence of different groups of the society and creates a societal structure in which people live in peace.

- Increases productivity and ensures the intellectual and moral development of all humans because it brings different mental resources together.

- Increases the creative problem-solving skills by applying many different perspectives for the solution of a problem. Increases the positive relations between people by the achievement of common goals and values. Decreases prejudice by bringing different individuals together and letting them interact. Revitalizes societies with the richness of different cultures and helps create a refined world-view.

Researchers who oppose multicultural education have, even though none have a rigid attitude, pointed out some problems arising from multicultural education (Codding \& Bergen, 2004). Several researchers argue the weaknesses of multicultural education as follows:

- The most criticized point of multicultural education in the literature is the lack of an agreed upon definition. The most definition by the proponents of multicultural education is Banks's (2008) definition stating that it is a notion, a reform movement, and a process. Since this definition is overly general, it creates a weakness allowing the practitioners to interpret it as they see fit. Some negative results arising from the practice can result instead of the positive objectives (Thomas et al., 1994).

- Many researchers, while studying multicultural education, emphasized race and ethnicity and neglected other differences like gender, religion, language and social class (Furman, 2008).

- Many studies conducted on teachers who are the implementers of multicultural education have shown that they do not believe in multicultural education (Gay, 
2003), that they cannot find enough support from the institution they work in (Van Hook, 2002), and that they do not have sufficient knowledge on how to practice multicultural education.

- Overemphasizing multiculturalism creates an excessive ethnical awareness (Webster, 1997). Even though individuals have more than a single identity, the overemphasis on ethnic and racial identities makes these identities dominant and causes the individual to distance themselves from the mainstream culture and this constitutes a risk against the national integrity and social order (Glazer, 1997).

- Multiculturalism is a notion based on cultural relativism and claims that no culture is superior to another. But every culture considers its own values, norms, points of view and beliefs as superior than the others' (D'Souza, 1995).

Despite these dissenting opinions surrounding it, multicultural education, especially in the US, has come a long way in terms of curriculum (Banks, 2008). Establishment of a multicultural mentality in the society is very important for maintaining the social order and protecting the national integrity and unity.

Teachers' Role in Multicultural Education

Basbay and Kagnici (2011) state that, alongside those who consider multiculturalism as a positive and passive process, there are those who criticize multiculturalism by claiming that it can cause the deterioration of the social structure. Just like with all practices related to education, teachers have an important role in understanding and implementing multicultural education. Gay (1994) states that teachers generally perceive their own values, beliefs, and experiences as standard rules and that what they know and what they teach is governed by educational principles. She states that they may engage, knowingly or unknowingly, in erroneous educational practices because they do not understand the racial, social, and linguistic diversity of their students. Formal education, as Costa (1997) states, depends on the attitude and professional preparation of the teacher and this is even more important in multicultural classrooms. Pea (1997), in his analysis on teachers' perceptions, states that teachers put too little time into getting to know their students and they know very little about them for this reason. He also states that the experiences of students belonging to cultural minority groups are ignored by the teacher due to the teacher's perception and to the fact that he/she may not have taught similar students before. Aydin (2012) emphasizes the importance of training educators who can design educational programs starting from preschool in the establishment of an academic infrastructure that will implement a multicultural education system.

Washington (2003) states that teachers need three important basic skills, namely "understanding oneself", "understanding the culture of others," and "academicmulticultural qualifications". According to Basbay and Kagnici (2011), of the qualifications determined by the Ministry of National Education, those related to knowing the student, diversifying the education by taking individual differences into consideration, valuing, understanding and respecting the students and attaching importance to national and universal values necessitate that the teachers be at a certain level in terms of multiculturalism. NCATE 2006 attaches importance to 
teacher candidates' abilities to develop classroom settings by taking diversity into consideration and unifying the diversity; this document contains articles necessitating the teachers to possess these qualifications.

Polat (2009) states that the objective of education is to focus on, instead of to standardize, the student, accepting him/her as he/she is and developing his/her abilities and that, consequently, students need educators who consider multiculturalism natural and who can provide a multicultural education. Cirik (2008) emphasized that the main principles of learning and teaching should defend students against to racism, prejudice, sexism and other forms of discriminations Gorski (2000) indicates a strongly that teachers have a responsibility to continuously examine their own prejudices, partiality, and perceptions that can affect students' experiences. To become an effective multicultural educator and teacher, the teacher has to keep examining and transforming himself/herself. According to Bigatti et al. (2012), being a multicultural teacher involves more than presenting course content on diversity. It necessitates ensuring an inclusive and progressive classroom setting, feeling the communication between the students, and facilitating the students' ability to learn with the help of different educational techniques and evaluations (Gay, 2004b). Aydin (2013) states that educators can develop the students' ethnic, linguistic and cultural literacy, support their self-esteem and development, teach them the importance of inclusiveness and tolerance, encourage them to work and interact with people who are different than them and provide a more effective education by these means. Based on these statements one can conclude that teachers have a critical role in the conception and implementation of multicultural education based settings and programs.

\section{Research Design}

\section{Method}

In this study, the researchers used a qualitative case study approach. According to Bogdan and Biklen (1992), a case study is the detailed analysis of an environment, a single document, or a special event. Denzin and Lincoln (2011) have stated that, despite the vastness of statistical methods, the main difficulty of the case study is to come up with a study that is detailed, rich, and complete, and that includes all case variances. The study has been conducted in the scope of the multicultural education class provided by the curriculum and instruction department at one of the largest state universities in Turkey. The study group was selected with purposeful sampling. According to Erdogan and Yazicioglu (2007), in purposeful sampling, the sample is selected from the population by determining the units that represent the needed data. Necessary human subject permissions were obtained from the Social Sciences Institute (SBE) of the university.

Research Sample

The participants of this study consist of nine doctoral students taking the multicultural education class in spring 2012-2013 academic years, five of which are teachers and four are academicians (T1, T2, T3, T4, T5 \& A1, A2, A3, A4). All of the participants selected the Multicultural Education class voluntarily and gave written permission for the utilization of information gathered from them as academic data. 
The data were collected in the scope of the volunteering principle. Participants consist of five female and four male, and their average age is 31.

Research Instrument and Procedure

In this study, the data was collected through "triangulation" of multiple data collection methods. Triangulation overcomes the limitations of one data collection method by using another data collection method in conjunction and thus increases the validity and reliability of the findings (Yildirim \& Simsek, 2008).

Interview. Over the course of the study, the students were asked structured and unstructured questions. The questions were mostly aimed at finding out their points of view, attitudes, and opinions concerning multiculturalism and multicultural education. All communications and questions' answers have been written by the researchers during rest of semester which covers fifteen weeks.

Weekly Discussion Board. For seven out of a total of fifteen weeks that the Multicultural Education class was taught, articles published on a national and international scale about multicultural education were sent every week to students by email. Every student was asked to read these articles and write an essay in accordance with the questions sent. These essays were posted on the discussion board and the multicultural education class was structured around these discussions. A total of 26 articles, six articles for the first week, three for the second week, two for the third week, seven for the fourth week, four for the fifth week and four for the sixth week were sent, all relating to the subjects to be handled. The students were asked to analyze these and write their essays accordingly.

Examination papers and students course materials. An examination consisting of 14 structured interview questions was conducted to measure and evaluate the students' multicultural education perceptions. To ensure the validity and reliability of the examination questions, three experts were consulted and the examination was conducted after the questions were structured. The students were informed before the examination that the first 12 questions were interpretation questions and that they did not have any evaluation purpose and that the last two questions were questions of knowledge and that they would be evaluated accordingly.

Observation Form. Students' attitudes were observed throughout the period and the changes in their statements and behaviors were recorded on the observation form. Particularly, their initial knowledge, attitude and prejudices and the positive and negative changes during the lectures have been recorded.

\section{Data Analysis}

All interviews were taped and transcribed after importing to the digital computer media. Qualitative data were analyzed with the content analysis method and the results were made into reports. Content denotes what is contained and content analysis is the analysis of what is contained in a message. Broadly content analysis may be seen as a method where the content of the message forms the basis for drawing inferences and conclusions about the content (Lal Das, \& Bhaskaran, 2008; Nachmias \& Nachmias, 1976)..Further, content analysis falls in the interface of observation and document analysis. It is defined as a method of observation in the sense that instead of asking people to respond to questions, it "takes the 
communications that people have produced and asks questions of communications" (Kerlinger, 1973, as cited in Prasad, nd., p.2). Therefore, it is also considered as an unobtrusive or non-reactive method of social research. In addition, discovered themes have been verified with the Nvivo 10 software and their correctness has been confirmed by five peers who enrolled in doctoral program in education.

Observation is a method used to define a behavior emerging in an environment in a detailed manner. The most important property of observation is that it provides first hand data to the researcher (Yildirim \& Simsek, 2008). The preferred method of this study, unstructured field study, is conducted in the natural environment of the behavior and it is generally carried out with a method called 'participatory observation' in which the researcher participates in the environment. In participatory observation, the observer is with the observees and acts like one of them (Karasar, 2007). In this study, this type of observation was preferred and an observation form was used to facilitate the recording of the data. Document analysis, on the other hand, consists of the analysis of written material containing information on the researched notions and its validity increases when used with other data collection methods like observation and interview through data triangulation (Yildirim \& Simsek, 20088). Students' essays and examination papers were analyzed with the thematic and content analysis method. By taking all the data into consideration, the most emphasized notions by the participants were coded. The most important themes discovered are analyzed and presented.

\section{Role of the Researchers}

In this study, the researchers attempt to present the findings of the process as is and strive to not project their own views. Observations were carried out by two researchers and the interviews by one. The documents were analyzed separately by the two researchers, the findings were compared, and a common conclusion was reached with the results then verified with the Nvivo 10 software. After the as-is presentation of the findings, personal opinions and the findings have been handled in the discussions section.

Validity and Reliability

a) To increase the internal validity (plausibility) of the study, triangulation was used. The findings have been presented based observation, interview, and document analysis. After the taped questions and answers, the students have confirmed their own responses. In addition to this, the students confirmed their views and cleared up misunderstandings by reading their weekly essays in the classroom. The study had a nine week duration, which enabled a long-time interaction with the participants and collection of deep data.

b) To increase the reliability (consistency) of the study, direct quotations have been used in the presentation of the findings. Two researchers conducted the observations, and these observation findings were compared at the reporting phase in order to reach common conclusions. The researchers read the interview and observation findings and possible codes and themes were thus determined and then verified by the Nvivo 10 software. 


\section{Results}

The analysis of the examination papers and essays of the participants leads to the observation that all participants agree on the necessity of multicultural education and have a positive point of view toward it. The most emphasized notions are equality, justice, and democracy and all participants agreed that personal differences have to be taken into consideration and that it's richness of cultural and diversity. Tolerance, respect, and peace are also among the most reiterated notions.

\section{Theme One: Equality}

The analysis of the documents obtained during the application phase of the research reveals that the word equality has been repeated 37 times by the participants and that this is the most used description. Almost all of the nine participants emphasized the notion of equality and stated that multicultural education ensures equality. Five participants defined multicultural education with an emphasis on equality. One participant (A1) defined multicultural education as follows:

Multicultural education is the constitution of the umbrella of the teaching programs in a way to include all kinds of difference and means education in equal conditions for every individual regardless of their religion, language, race, gender and physical and mental differences.

Another participant's (A3) definition of multicultural education emphasizes again the notion of equality:

Multicultural education is, in the most general sense, offering equal chances of success to students having different races, religions, languages, cultures etc.

All nine participants stated that the biggest advantage and strength of multicultural education is 'ensuring the equality' and that this also brings peace. For example one participant (A1) who considers equality as the greatest gain of multicultural education explained:

The biggest advantage of multicultural education is the mention of all individuals of the society in the educational system and the extension of an egalitarian approach to all schools.

Similarly, another participant (T4) expressed the opinion that the biggest advantage of multicultural education is to ensure the equality with the following sentence:

I think its biggest advantage is not to abandon students coming from disadvantaged groups of the society to their fate and support them instead and thus ensure them an equal right of education.

Some participants stated that if they prepared a multicultural program, they would promote the ability for all groups to express their opinion equally and emphasized its importance. One participant (T2) said

The program would contain points like common education in two languages, reduction of prejudices and equal right to express their opinion for all peoples" in this regard while another stated "I would prepare the 
curriculum in such a way that would represent different groups of the society equally.

Yet another participant (A2) expressed his opinion about the content of the program as follows:

Respect to differences, equality of opportunity in education and the contents of elements like democracy and social justice should be handled abundantly educational programs.

The participants also mentioned the factor of equality in the list of descriptions that can be done to promote and popularize multicultural education. One participant stated the need for "the school personnel to receive training emphasizing the advantages of multiculturalism in school including notions like diversity, culture, equality, human values etc." and another emphasized "a systematic, equal and organized multicultural education has to be legislated first".

All participants stated that different strategies and methods can be used for different social classes and stressed its necessity. They pointed out that the classes taught should also contain the notion of equality and gave examples. One participant (T5) expressed his/her opinion as follows:

For different classes, many elements can be included in the learning environment. Traditions and special days of different religions (Ramadan Feast, Christmas Day etc.), different ethnic cultures (blacks, whites, Asians, Kurds, Turks etc.), all kinds of activities against prejudice and emphasizing gender equality should take their place in the classroom.

Another participant (T1) listed what can be done for different classes as follows:

In Project based learning environments, each student can prepare projects and homework projecting their own mother tongue and culture. The UK is performing this very well, so can we. Also, we can stop using civics classes as a tool for assimilation and transform it into a higher quality class where universal values like democracy, pluralism, social justice and equality.

A general analysis of the answers provided by the participants reveals that the notion of equality is stressed and that there is a consensus about multicultural education's importance in ensuring equality.

\section{Theme Two: Democracy}

The analysis of the documents obtained during the application phase of the research reveals that the word democracy was used 29 times by the participants and it is one of the most often repeated notions. All nine participants emphasized the notion of democracy and talked about the importance of multicultural education in forming a democratic society. One participant cited the immaturity of Turkish democracy as one of the obstacles before the application of multicultural education and two participants emphasized the notion of democracy while defining multicultural education. These definitions were worded as follows: 
Multicultural education is a democratic reform movement where students having many differences like race, religion, language and gender have an equal right of education. (T3)

It is the ability of individuals from different cultures regardless of their languages, religions, races or genders to continue their education in the same learning environment in the scope of democracy and social justice. (A4)

Seven of the nine participants mentioned concerns that multicultural education might divide the society and deteriorate its unity and two emphasized assimilation. The comments on these concerns stated that multicultural education would, on the contrary, contribute in the formation of a democratic environment. One participant (T4) expresses his/her opinion as follows:

Multicultural education does not divide a society or a country. On the contrary, in societies having differences, it helps them survive in a more democratic framework.

One of the most cited advantages and strengths of multicultural education is its ability to form a democratic environment. One participant (T2) stated;

To be able to apply notions like equality and democracy in a healthier way" as an advantage of multicultural education while another claimed "to help the development of sciences like tolerance, brotherhood, rights, law and democracy", yet another said "that it ensures a democratic social order.

Also, one participant (T5) stated as follow;

Trying to apply it in societies where democracy is not well developed may cause social unrest", mentioning the importance of the existence of a democratic society for multicultural education to be applied.

The opinion that the integration of multicultural education into the Turkish educational system would bring about the development of a consciousness of democracy was suggested and one participant (A2) listed the advantages of this as follows:

There would be an opportunity to benefit from different cultures, a consciousness of democracy for all would develop, an environment of trust and peace would be formed away from fear and concerns, it would ensure cultural interaction, it would cause social transformation and progression.

Another participant (A1) expressed his/her opinions on the matter as follows:

I think that a transition to a much more democratic educational system taking individual needs and differences into account would be the biggest gain.

When listing what is necessary for multicultural teacher training programs for the Turkish school system, the idea of democracy was emphasized again and it was stressed that the programs must be based on democratic principles. One participant (A3) said: 
I would strive to make it a program based on Islamic tolerance, referencing successful historical examples conforming the universal principles of human right and democracy.

Another participant (A4) expressed his/her opinion as follows:

Our academicians who will train the teachers have to communicate that education must be carried out in a framework of love, respect, social justice and democracy and they should practice accordingly.

When the participants' statements are analyzed in general, it is revealed that the notion of democracy was stressed quiet often and that multicultural education's contributions to the creation of a democratic society and democratic environment were often reiterated.

Theme Three: Justice

An analysis of the documents obtained during the application phase of the research reveals that the word justice was used 17 times by the participants and that it is another of the most repeated notions. All nine participants emphasized the notion of justice and mentioned the importance of multicultural education in ensuring justice. Two participants mentioned this concept while defining multicultural education and two other participants stated that multicultural education is related to the notion of social justice. One of the multicultural education definitions is as follows:

Multicultural education is to accept everyone regardless of their religion, language, ethnic background and gender with their own values. It is the ability to approach everyone with justice, tolerance and impartiality. (T5)

About the notions that multicultural education is related to and its role on the establishment of justice, two participants express the following opinions:

Multicultural education is related to notions like difference, equality, social justice etc. and it is stated that multicultural education must be practiced for societies living in peace. (A3)

Multicultural education is a theory that first appeared and developed in the US following the Civil War but it is also a quest for a solution to eliminate the social injustice in countries like the US, Canada and the UK where the demographics change with the increase of minorities. In this context, multicultural education is related to notions like democracy, citizenship, immigration, differences, social justice, minority rights and integrations. (T4)

The fact that multicultural education stresses the notion of justice and that it has a quality that can establish justice in the society was indicated as strength of multicultural education by four participants. One participant emphasized multicultural education's importance for human rights and social justice, another stated that multicultural education infuses the sentiment of equality and justice to a participatory society, yet another mentioned multicultural education's establishment of social justice and yet another discussed its contribution to the sentiment of justice and self-esteem. 
Social justice was described as being one of the necessary elements for the implementation of multicultural teacher training programs. One participant (A2) stated:

Respect to differences, equality of opportunity in education and the contents of elements like democracy and social justice should be handled abundantly educational programs.

Another participant (A4), on the matter of teacher training, stated:

Our academicians who will train the teachers have to communicate that education must be carried out in a framework of love, respect, social justice and democracy and they should practice accordingly.

Participants also emphasized the notion of social justice when talking about the steps that can be taken to improve the teacher training programs. One participant (A2) stated:

First of all, teachers should be trained to embrace differences. The most fundamental quality that a teacher has to have is justice. In this context, justice and social justice have to be included to the program.

A general analysis of the answers reveals that multicultural education's importance in establishing social justice is often stressed and considered very important. All participants had positive thoughts on multicultural education. Most participants emphasized that multicultural education contributes societies with social justice, equality, and democratic values for each individuals. Thus, both teachers and academics should be trained regarding multicultural education for democratic societies.

\section{Observation Findings}

At the first week of the study, we asked the students about their ethnic background and religion and we observed that some of them were reluctant to give this information or comment. After the executive of the class defined multiculturalism and multicultural education, introduced the subject and revealed his/her own ethnic background and religion, students started to reveal more information. Next week, students who read the relevant articles and wrote their essay discussed what they understood from the lectures, their concerns about multicultural education, the points that surprised them, the rationale and objectives of multicultural education, the reasons why it is beneficial to students coming from different cultures and its possible benefits for the Turkish educational system. Students most often expressed their concerns that multicultural education could divide the country. However after the readings they performed during the following weeks, we observed that they decided that multicultural education is actually a unifying education design and that it aims at ensuring a more egalitarian, more democratic, and more just social order. All students agreed that multicultural education is necessary and important and that multicultural education is very important for students coming from different cultures to live their own values without being assimilated and to be more successful. 


\section{Discussion and Conclusion}

Multicultural education is a field of study that helps students acquire the knowledge and skills necessary for participating to the democratic society and those coming from different cultures to have equal opportunity of education (Halvorsen \& Wilson, 2010). Analysis of educators' opinions on multicultural education and interpretation of the findings to help reorganize the training programs will contribute to a more equal, more democratic and a more just educational system. The analysis of the findings of this study reveals that all participants state that multicultural education is important and necessary and they emphasized, above all, equality, democracy and justice on the matter of multicultural education.

The study's findings show that multicultural education, besides many other advantages, ensures equality. D'Souza (1995) states that multiculturalism considers all cultures as equals and none of them are superior to another. Nelson (2001) states that valuing diversity in socially organized belief systems, races and cultures is the key to providing equal educational opportunities to all students. ITARI (1991) identifies the central value of multicultural education programs as education of different groups around values like equality, justice, human rights and democracy. Sleeter and Grant (1987) emphasizes that multicultural education movement is a civil rights movement aiming at making education equal for all social groups. Sharma (2011) related an effective education in multicultural classrooms to providing equal opportunities for academic success and personal development. Pang (2001) stresses that multicultural education can be a starting point for the elimination of inequalities in the society due to its decisiveness in treating the deficiencies and mistakes of the current educational system. In this study, in parallel with the literature, the most mentioned notion by the doctorate students was equality and it was stated that multicultural education will contribute to everyone having equal opportunities and equal right to education.

The notion of democracy was also one of the most reiterated notions by the participants. Similarly, there are many studies mentioning the positive contribution of multicultural education to democracy. Cole et al. (2003), define multicultural education as a learning and teaching approach based on democratic values and beliefs and pointed out the cultural diversity in an interconnected world with cultural pluralism. Nieto (1992) defines multicultural education as an educational system reform aiming at providing education without regard to any kind of discrimination to develop the relations between the individuals in the classroom. Polat (2009) indicates that the quality of multicultural education is proportional to the democratic practices of the country. Gay (2003) states that one of the strengths of multicultural education is its emphasis on notions like democracy, equality, and justice. Banks (2008) states that the goal of a multicultural education program is to democratize the education programs in order to provide everyone with a more impartial and free point of view. Similarly, in this study the participants stated that multicultural education would strengthen the democracy in the society and contribute to a democratic learning environment.

Justice is yet another notion that was often emphasized in this study. Aldridge, Calhoun and Aman (2000) state that multicultural education helps the society be more tolerant and more just, and realize that it is richer than any of its constituents. 
Herring and White (1995) also state that teachers should use non-sexist language and implement an egalitarian education. According to Hunter (1974), multicultural education is the structuring of the education in the context of equality, mutual respect, acceptance, understanding and moral principles for realizing the democratic ideals, meeting the needs of different groups of the society and ensuring the social justice. Grant (1977b) defines multicultural education as an educational approach deriving all the necessary content for a good education and to better understand the global society from the existing cultures of the students based on social justice for all humans, and the power of alternative life styles, human rights and diversity. According to Banks (2008), one of the main goals of an educational system promoting a multicultural literacy is to help the student develop a democratic and egalitarian society, know, be sensitive and act. In this study, the participants, similar to the findings in the literature, mentioned the importance of multicultural education in ensuring justice, they emphasized the notion of justice in their definitions of multicultural education and related multicultural education to the notion of social justice.

In a way, the need for people with different characteristics and cultures to live with equal rights and every group of the society to have an equal and democratic structure make multicultural education a necessity. Stradling (2003) states that multicultural education creates a possibility to accept that there are different points of view and that they are equal and to understand how the other side feels. Even though the number of studies on multicultural education conducted in Turkey is limited, we recommend that more studies should be conducted like they are in countries with more advanced democracies and that the educational programs should be extended to include multicultural education.

\section{References}

Aldridge. J.,Calhoun, C., \& Aman, R. (2000). 15 misconceptions about multicultural education. Focus on Elementary, 12(3).

Ameny-Dixon, G. M. (2004). Why multicultural education is more important in higher education now than ever: A global perspective. International Journal of Scholarly Academic Intellectual Diversity, 8(1), 1-9.

APA. (2002). Guidelines on multicultural education, training, research, practice, and organizational change for psychologists. Retrieved on December 04, 2013, from http://www.apa.org/pi/oema/resources/policy/multiculturalguidelines.aspx

Aydin, H. (2012). Multicultural education curriculum development in Turkey. Mediterranean Journal of Social Sciences, 3(3), 277-286. Doi:10.5901/mjss.2012.v3n3p277

Aydin, H. (2013). Dünyada ve Türkiye'de Çokkültürlü Eğitim Tartışmalar ve Uygulamalar. [Discussions and Practice of Multicultural Education in Turkey and in the world.]Ankara: Nobel Publishing House. 
Banks, J. A. (2008).Çokkültürlü Eğitime Giriş [Introduction to Multicultural Education]. (H. Aydin, Çev.)İstanbul: Anı Yayıncılık.

Banks, J.A. (2010). MulticulturalEducation: Characteristics and Goals. J.A.Banks \& C.H.M.Banks (Eds), Multicultural Education:Issues and Perspectives (pp.3-30) (7th Ed.). ABD: Wiley.

Başbay, A. \& Kağnıcı D.Y. (2011). Çokkültürlü Yeterlik Algıları Ölçeği: Bir Ölçek Geliştirme Çalışması [Perceptions of Multicultural Competence Scale: A Scale Development Study]. Eğitim ve Bilim, 36 (161), 199-212.

Bigatti, S. M.,Gibau, G. S., Boys, S., Grove, K., Ashburn-Nardo, L., Khaja, K., \& Springer, J. T. (2012).Faculty Perceptions of Multicultural Teaching in a Large Urban University. Journal of theScholarship of Teachingand Learning,12(2), 78-93.

Bogdan, R. ve Biklen, S. K. (1992). Qualitative Research for Education. Boston: Allynand Bacon.

Brodkin, K. (1998). How the Jews Became White Folks and What That Says About Race in America. New Brunswick, NJ: RutgersUniversityPress.

Cırık, İ. (2008). Çokkültürlü eğitim ve yansımaları [Multicultural Education And Its Reflections]. Hacettepe Üniversitesi Ĕ̆itim Fakültesi Dergisi, 34, 27-40.

Codding, R. \&Bergen, K. (2004). Multicultural education: An Extensive Literature Review. Retrieved on November 23, 2013, from http://humboldt.edu/sociology/downloads/senior_projects/2004Codding\% 26Bergen.pdfadresinden erişildi.

Cole, D.,Bennett, C., \&Thompson, J. N. (2003). Multicultural teacher education: Implications for critical mass and all-minority classes at a predominantly White university. Journal of Classroom Interaction, 38 (1), 17-28.

Costa, X. B., (1997), Intercultural education: Theories, policies and practices.Brookfield, Vermont: Ashgate.

Denzin, N. K. \& Lincoln, Y. S. (2011). The SAGE Handbook of Qualitative Research. Thousand Oaks, CA: SAGE Publication.

Dickeman, M. (1973). Teaching Cultural Pluralism. In J. A. Banks (Ed.), Teaching Ethnic Studies: Consept and Strategies(pp. 5-25). Washington, DC: National Council for the SocialStudies.

D'souza, D. (1995). Theend of racism: Principles for a multiracial society. New York: FreePress.

Fordham, S. (1988). Racelessnessas a Factor in Black Students School Success: Pragmatic Strategy or Pyrrhic Victory? Harvard Educational Review, 58(1), 5484. 
Furman, J. S. (2008). Tensions in Multicultural Teacher Education Research Demographics and the Need to Demonstrate Effectiveness. Educationand Urban Society, 41(1), 55-79.

Gaff, J. G. (1992). Beyond politics: The educational issues inherent in multicultural education. Change, 24 (1), 30-35.

Gay. G. (1994). A synthesis of scholarship in multicultural education. Urban Monograph No. RI88062012), OakBrook, Illinois, North Central Regional Educational Laboratory.

Gay, G. (2000). Culturally Responsive Teaching: Theory, Research and Practice. New York: Teacher College Press.

Gay, G. (2003). The Importance of Multicultural Education. Association for Supervision and Curriculum Development, pp.30- 35. Retreieved on December 3, 2013, from http://www.achievementseminars.com/seminar_series_2008_2009/readings /importance_multicultural_education.pdf

Gay, G. (2004b). Curriculum theory and multicultural education. In J. A. Banks\& C. A. Banks (Eds.), Handbook of research on multicultural education (2nd ed.) (pp. 30-49), San Francisco:JosseyBass.

Glazer, N. (1997). We Are All Multiculturalist Now. Cambridge, Massachusetts: Harvard UniversityPress.

Gorski, P. C. (1999). A Brief History of Multicultural Education. Retrieved on November 20, 2013, from http://www.edchange.org/multicultural/papers/edchange_history.html

Gorski, P. (2000). The challenge of defining a multicultural education. Retrieved on November 22, 2013, from http://www.edchange.org/multicultural/initial.html

Grant, C. A. (1977b). Multicultural education: Commitments, issues and applications. Washington, D.C.:Association for Supervision and Curriculum Development.

Halvorsen, A. L. \& Wilson, S. M. (2010). Social Studies Teacher Education. InPeterson, P., Baker, E., \&McGaw (Eds), International Encyclopedia of Education (3rd ed.) (pp.719-737), Oxford: ElsevierAcademicPress.

Herring, R.D.,\& White, L.M. (1995). School counselors, teachers, and the culturally compatible classroom: Partnerships in multiculturaleducation. Journal of Humanistic Education and Development, 34(2), 52-64.

Hohensee, B. J, \& Derman-Sparks. L. (1992). Implementing an Anti-BiasCurriculum in Early Childhood Classrooms. ERIC Digest. 
Hunter, W.A. (Ed.).(1974). Multicultural education through competency based teacher education. Washington, D.C.: American Association of Colleges for Teacher Education.

Kaya, İ. \& Aydın, H. (2014). Çoğulculuk, Çokkültürlü ve Çokdilli Eğitim. [Pluralism, Multicultural, and Multilingual Education]. Ankara: Anı

Publishing.Kerlinger, F.N. (1986). Foundations of behavioural research (3rd ed). New York: Holt, Rinehart and Winston.

Kodish, B.I. (2003). What we do with language-what it does with us. ETC: A review of general semantics, 60(1), 383-384.Lal Das, D.K and Bhaskaran, V (eds.). (2008) Research methods for Social Work, New Delhi:Rawat, pp.173-193.

Lee, K. S.,\&Carrasquillo, A. (2006). Korean college students in United States: Perceptions of professors and students.College Student Journal, 40(2), 442-456.

Mitchell, B. M. (1999). Encyclopedia of multicultural education. Westport, Conn: Greenwood Press.

Morey, A. \&Kitano, M. (Eds.). (1997). Multicultural course transformation in higher education: A broader truth. Boston: Allynand Bacon. Nachmias, D. \& Nachmias, C. (1976). Content analysis. In Research methods in thesocial sciences (pp.132139), UK: Edward Arnold.

Nelson, T. (2001). Editor's Introduction: Advancing educational opportunities in a multicultural society. Teacher Education Quarterly, 26(3), 147-156.

Nieto, S. (1992). Affirming diversity: The sociopolitic alcon text of Multicultural Education. New York: Longman.

Pang, V. O. (2001). Multicultural education: A caring-centered, reflectiveapproach. New York: McGraw- HillPress.

Parekh, B., (2002), Çokkültürlülüğ̈̈ Yeniden Düşünmek, Kültürel Çeşitlilik ve Siyasi Teori. [Rethinking Multiculturalism- Cultural Diversity and Political Theory]. Çev: Bilge Tanrıseven, Ankara: Phoenix Yayınevi.

Pena, R. A., (1997). Cultural differences and the construction of meaning: Implications for the leadership and organizational context of schools. Education Policy Analysis Archives, 5(10), 1-19.

Polat, S. (2009). Öğretmen Adaylarının Çok Kültürlü Eğitime Yönelik Kişilik Özellikleri. [Teachers' Personality Traits Towards Multicultural Education] International Online Journal of EducationalSciences, 1 (1), 154 - 164.Prasad, B., D. (nd). Content Analysis:A method in Social Science Research. Retrieved on December 29, 2013, from http://www.css.ac.in/download/Content\%20Analysis. \%20A\%20method\% 20 of $\% 2$ _ OSocial $\% 20$ Science $\% 20$ Research.pdf 
Reitz, J. G. (2009). Assessing Multiculturalism as a Behavioural Theory. InReitz, J. G., Breton, R., Dion, K. K., \&Dion, K. L. (Eds.), Multiculturalism and Social Cohesion: Potential and Challenges of Diversity(s. 1-47). Toronto, Canada: Springer Science + Business Media Press.

Schlosser, L. K., (1992). Teacher distance and student disengagement: School lives on the margin.Journal of TeacherEducation, 43(2), 128-140.

Sharma, S. (2011). Multicultural education: Teachers' perceptions and preparation. Journal of CollegeTeaching E Learning,2(5), 53-64.

Sleeter, C. E.,\& Grant, C. A. (1987). An analysis of multicultural education in the United States. Harvard Educational Review, 57(4), 421-445.

Stradling, R. (2003). 20. Yüzyıl Avrupa Tarihi Nasıl Öğretilmeli?.[How Should be Thought 20th Century European History]. İstanbul: Türkiye Ekonomik ve Toplumsal Tarih Vakfı Yayınları.

Thomas, D.G.,Chinn, P., Perkins, F., Carter, D.G. (1994). Multicultural Education: Reflections on Brown at 40. The Journal of Negro Education. 63(3), 460-469.

Van Hook, C.W. (2002). Preservice Teachers' Perceived Barriers to the Implementation of a Multicultural Curriculum. Journal of Instructional Psychology. 29(4).

Washington, E. D. (2003). The multicultural competence of teachers and challange of academic achievement. In D. B. PopeDavis, H. L. K. Coleman, W. M. Liu\& R. L. Toporek (Eds).,Handbook of multicultural competencies in counseling and psychology. California:Sage Publications.

Webster, Y.O. (1997). Against the Multicultural Agenda: A Critical ThinkingAlternative. Westport, Connecticut: Praeger Publishing.

Woodrow, D.,\&Sham, S. (2001). Chinese pupils and their learning preferences. RaceEthnicity and Education, 4(4), 377-394.

Yıldırım, A. \& Şimşek, H. (2008). Sosyal Bilimlerde Nitel Araştırma Yöntemleri [Qualitative Research Methods in Social Sciences].Ankara: Seçkin Yayıncılık. 


\section{Doktora Öğrenimi Gören Öğretmen ve Akademisyenlerin Çokkültürlü Eğitim Algılarının İncelenmesi}

\section{Özet}

Atıf:

Aydin, H. \& Tonbuloğlu, B. (2014). Graduate students perceptions' on multicultural education: a qualitative case study. Eurasian Journal of Educational Research, 57, 29-50, http://dx.doi.org/10.14689/ejer.2014.57.3

Problem Durumu: Çokkültürlü eğitim; ırkçılığı ve asimilasyonu reddederek ve her türlü farklılığa saygı göstererek, demokratik değerler çerçevesinde kültürel çoğulculuğu sağlamak için eşit eğitim ve öğrenim fırsatları oluşturma süreci olarak tanımlanabilir. Çokkültürlü eğitimin amaçları genel bir ifadeyle farklı gruplar arasındaki iletişimi geliştirmek, saygı ve hoşgörüyü artırmak, bireylerin kendisiyle barışık olmalarını sağlamak ve daha demokratik, adil bir toplum düzeni oluşturmak olarak sıralanabilir. Çokkültürlü eğitimin temelinde bulunan eşitlik, saygı, barış, vb kavramlarla ve tüm öğrencilere eşit başarı olanağı sağlama amacıyla uyumlu bir şekilde uygulanması için temel görev öğretmenlere düşmektedir. Öğretmenlerin rolü, çokkültürlü eğitimin amaç ve kapsamına uygun bir şekilde uygulamasında olduğu kadar farklı gruplara mensup tüm öğrencilerinden yüksek beklentilerinin olmasında da belirleyicidir. Araştırmalar öğretmenin öğrencilerinden beklentilerinin öğrenci başarısını etkilediğini ortaya koymuştur.Buradan hareketle öğretmenlerin çokkültürlü eğitim ile ilgili bilgi ve olumlu tutum sahibi olmasının, tüm öğrencileri için yüksek başarı hedeflemesini sağlayacağı söylenebilir.Çokkültürlülükle ilgili yapılmış birçok araştırma sonucu, kültürün eğitim üzerinde yadsınamaz bir etkisinin bulunduğunu gösterdiği halde öğretmen, öğretmen adayı ve yöneticilerin çokkültürlülükle ilgili yeterince bilgi sahibi olmadığını ortaya koyan araştırmalarmevcuttur.Bu araştırmadan elde edilecek verilerin, günümüzde birçok ülkede uygulanan ve Türkiye' nin eğitim programlarında da yer verilmesi beklenen çokkültürlü eğitim uygulamaları hakkında ilgili literatüre katkı sağlayacağı umulmaktadir.

Araştırmanın Amacı:Bu araştırmanın amacı, her biri üniversite- lise veya ilköğretim düzeyinde öğretmenlik yapan ve eğitim programları ve öğretim bölümünde doktora eğitimini sürdüren kişilerin çokkültürlü eğitim algılarını ve değerlendirmelerini öğrenmektir.

\section{Araştırmanın Yöntemi:}

Nitel türdeki araştırmada durum çalışması deseni kullanılmıştır. Çalışmada "durum" olarak doktora öğrenimi gören öğretmen ve akademisyenlerin çokkültürlü eğitim algıları incelenmiştir. Araştırma, Türkiye'deki en büyük devlet üniversitelerinden birinin Eğitim Bilimleri bölümünde, doktora düzeyinde verilen Çokkültürlü Eğitim dersi kapsamında gerçekleştirilmiştir. Bu araştırmanın çalışma 
grubunu, 2012-2013 eğitim- öğretim y1lında bu dersi alan beşi öğretmen, dördü akademisyen olmak üzere dokuz doktora öğrencisi oluşturmuştur. Nitel araştırma yöntemlerinden yapılandırılmamış görüşme, gözlem, alan notları ve doküman analizi kullanılmıştır. Sonuçların daha objektif olması açısındanek olarak haftalık tartışma yazıları (discussion board), sınav kağıtları ve gözlem formu kullanılmıştır. Bütün görüşmeler ses kaydı altına alınmış, sonra bilgisayar ortamına aktarılarak raporlaştırılmıştır. Nitel veriler içerik analizi yöntemiyle çözümlenerek, sonuçları raporlaştırılmıştır.Araştırmacı süreçte bulguları olduğu gibi ortaya koymaya çalışmış ve düşüncelerini sürece yansıtmamaya önem göstermiştir. Araştırmanın iç geçerliğini (inandırıcılığını) artırmak için veri çeşitliliğine gidilmiş, bulgular gözlem, görüşme ve doküman analizlerine dayalı olarak verilmiştir. Ses kaydına alınan soru ve cevaplar raporlaştırıldıktan sonra çalışma grubuna tekrar okutularak katılımcıların teyidi alınmıştır. Görüşme ve gözlem bulguları ile doküman analizleri raporlaştırıldıktan sonra 2 alan uzmanına okutulmuş, onların görüşleri doğrultusunda düzenlemelerde bulunulmuştur. Araştırmanın güvenirliğini (tutarlığını) artırmak için ise bulguların sunumunda doğrudan alıntılara yer verilmiştir. Gözlem iki araştırmacı tarafından yürütülmüş, raporlama aşamasında bu gözlem bulguları karşılaştırılarak ortak yargılara varılmıştır. Görüşme ve gözlem bulguları ile döküman analizleri araştırmacılar tarafından okunarak olası kodlara ve temalara karar verilmiş, ardından bu tema ve kodların teyidi Nvivo 10 programı ile yapılmıştır.

Araştırmanın Bulguları:Araştırma bulguları analiz edildiğinde en çok vurgu yapılan kavramların eşitlik, demokrasi ve adalet olduğu görülmüş, çokkültürlü eğitimin bu kavramları güçlendireceği belirtilmiştir. Katılımcıların sorulara verdikleri cevaplar genel olarak analiz edildiğinde eşitlik kavramı üzerinde ciddi anlamda durulduğu ve çokkültürlü eğitimin eşitliği sağlama yönündeki önemi konusunda bir fikir birliğinin varlığı dikkati çekmiştir. Ayrıca çokkültürlü eğitimin demokratik bir toplum ve demokratik bir ortam sağlama konusundaki katkılarının sıkça belirtildiği, sosyal adaleti sağlama noktasındaki önemine sıkça vurgu yapıldığı ve bu özelliğinin çok önemsendiği görülmüştür.Bununla birlikte hoşgörü, sayg1 ve barış da sık tekrarlanan kavramlardan olmuştur. Yapılan gözlemler neticesinde ise ders yürütücüsünün yönlendirmesiyle her hafta gerekli makaleleri okuyarak ve çokkültürlü eğitimle ilgili verilen soruları tartışma yazısı şeklinde yazarak derse gelen öğrencilerin, sınıfta okuduklarından anladıklarını, çokkültürlü eğitim hakkındaki bazı endişelerini ve şaşırdıkları noktaları,çokkültürlü eğitimin gerekçe ve hedeflerini, farklı kültürlerden gelen öğrenciler için faydalı olmasının nedenlerini ve Türk eğitim sistemi için faydalı olacak endişeleri tartıştıkları görüşmüştür. Öğrenciler ilk hafta en çok çokkültürlü eğitimin ülkeyi böleceği endişesini taşıdıklarını ifade etmişlerdir. Ancak haftalar içinde yaptıkları okumalar doğrultusunda aslında çokkültürlü eğitimin birleştirici bir eğitim olduğunu ve daha eşit, demokratik ve adil bir toplum düzeni kurmayı sağladığını belirttikleri gözlenmiştir. Öğrencilerin tamamı çokkültürlü eğitimin gerekli ve önemli olduğu noktasında görüş birliğine varmış, farklı kültürlerden olan öğrencilerin asimile olmadan kendi değerlerini yaşatabilmeleri ve daha başarılı 
olabilmeleri için de çokkültürlü eğitimin ayrı bir önem taşıdı̆̆ını belirttikleri görülmüştür.

Araştırmanın Sonuçları ve Önerileri Bu araştırmada, literatürde belirtilenlere paralel olarak doktora öğrencilerinin en çok üzerinde durdukları kavramlar eşitlik, adalet ve demokrasi olmuştur. Katılımcılar, çokkültürlü eğitimin herkesin daha eşit fırsatlara ve eşit eğitim hakkında sahip olunmasına katkı sağlayacağını ifade etmişler, çokkültürlü eğitimin adaleti sağlama noktasındaki öneminden bahsetmişlerdir. Ayrıca farklı özelliklere ve kültürlere sahip kişilerin aynı toplumda eşit haklara sahip şekilde yaşayabilmeleri ve toplumun her kesimden insan için daha adil ve demokratik bir yapıya sahip olabilmesi içinçokkültürlü eğitimin bir bakıma zorunlu olduğunu belirtmişlerdir. Çokkültürlü eğitim alanında Türkiye'de yapılmış olan çalışma sayısı sınırlı olmakla birlikte, tüm gelişmiş ve demokrasinin tam olarak uygulandığı ülkelerde olduğu gibi Türkiye'de de bu alanda yapılan araştırmaların artırılması, eğitimlerin verilmeye başlanması ve eğitim programlarının çokkültürlülüğü kapsayacak şekilde geliştirilmesi önerilmektedir. 